Fetal Diagn Ther 1997;12:I-IV

\title{
Contents, Vol. 12, 1997
}

\section{Announcement}

1 Use of Urinary Beta-2-Microglobulin to Predict Severe Renal Damage in Fetal Obstructive Uropathy

Freedman, A.L.; Bukowski, T.P.; Smith, C.A.; Evans, M.I.; Berry, S.M.; Gonzalez, R.; Johnson, M.P. (Detroit, Mich.)

7 Prognostic Factors of Prenatally Diagnosed Gastroschisis

Luton, D.; De Lagausie, P.; Guibourdenche, .1.; Oury, J.F.; Vuillard, E.; Sibony, O.; Farnoux, C.; Aigrain, Y.; Blot, P. (Paris)

Serial Amniocenteses in the Management of Twin-Twin Transfusion Syndrome: When Is It Valuable?

Trespidi, L.; Boschetto, C; Caravelli, E.; Villa, L.; Kustermann, A.; Nicolini, U. (Milan) Modulation of B12 Dosage and Response in Fetal Treatment of Methylmalonic Aciduria (MMA): Titration of Treatment Dose to Serum and Urine MMA

Evans, M.I.; Duquette, D.A. (Detroit, Mich.); Rinaldo, P. (New Haven, Conn.); Bawle, E. (Detroit, Mich.); Rosenblatt, D.S. (New Haven, Conn.); Whitty, J.; Quintero, R.A.; Johnson, M.P. (Detroit, Mich.)

Assessment of Fetal Thyroid Function by Colored Doppler Echography

Luton, D.; Fried, D.; Sibony, O.; Vuillard, E,; Tebeka, B.; Boissinot, C; Léger, J.; Polak, M.;

Oury, J.F.; Blot, P. (Paris)

Prenatal Effects of Aqueous Plastic Extract on Offspring

Al-Hachim, G.M.; Al-Khatim, A.-S.A. (Jeddah)

Effect of Laser Coagulation on Placental Vessels: Histological Aspects

Van Peborgh, P.; Rambaud, C; Ville, Y. (Clamart)

Prenatal Diagnosis of X-Linked Ichthyosis Using Molecular Cytogenetics

Santolaya-Forgas, J.; Cohen, L.; Vengalil, S.; Field, F.; Rodriguez, A.; McCorquadale, M;

McCorquadale, D.J. (Chicago, Ill.)

Late Onset of Hydrops Fetalis following Intrauterine Parvovirus B19 Infection

Mielke, G. (Tubingen); Enders, G. (Stuttgart)

Fetal Functional Pulmonary Atresia with Ascites Resolving Spontaneously before Birth. A Case Report

Wk > ch, A.; Respondek, M.; Wl-och, S.; Sodowski, K.; Kaczmarek, P.; Wl-odarska, D.;

Rokicki, W.; Tomala, J. (L·odz)

Prenatal Diagnosis of Idiopathic Stenosis of the Ductus arteriosus Associated with Fetal Atrial

Flutter

Mielke, G.; Steil, E.; Gonser, M. (Tubingen)

Constriction of an Extremity after Amnioreduction in a TRAP-Like Sequence

von Eckardstein, S.; Reihs, T.; Crombach, G. (Düsseldorf)

Diagnosis and Successful in utero Treatment of a Fetal Goitrous Hyperthyroidism Caused by

Maternal Graves' Disease. A Case Report 
Heckel, S.; Favre, R.; Schlienger, J.L.; Soskin, P. (Strasbourg)

Management of a Triplet Gestation Complicated by Uterus didelphys

Ginsberg, N.A.; Strom, C; Verlinsky, Y. (Chicago, Ill.)

Varying Clinical Course of Large Placental Chorioangiomas.

Report of 3 Cases

Zoppini, C; Acaia, B.; Lucci, G.; Pugni, L.; Tassis, B.; Nicolini, U. (Milan)

65 Editorial

Michejda, M. (Washington, D.C.)

66 Nonimmune Hydrops fetalis Caused by Intrauterine Human

Parvovirus B19 Infection: A Case of Spontaneous Reversal in

utero

Faure, J.-M.; Giacalone, P.-L.; Deschamps, F.; Boulot, P. (Montpellier)

68 Fetal Rat Brain Injury: Effect of Transient Maternal Hypoxemia

Hallak, M.; Kupsky, W.J.; Hotra, J.W.; Irtenkauf, S.M. (Detroit, Mich.)

72 Fetal Breathing Movements Are Associated with Changes in Compliance of the Left

Ventricle

Miyague, N.I.; Ghidini, A.; Miyague, L.L.T. (Washington, D.C.) 76 Effect of Endoscopic White

Light on the Developing Rat Retina

Bonnett, M.L.; Quintero, R.A.; Carreño, C; Crossland, W.J. (Detroit, Mich.)

81 Chorioamniotic Membrane Separation: A Potentially Lethal Finding

Graf, J.L.; Bealer, J.F.; Gibbs, D.L.; Adzick, N.S.; Harrison, M.R. (San Francisco, Calif.)

85 Doppler Velocimetry of the Umbilical Artery as a Predictor of Pregnancy Outcome in

Pregnancies Characterized by Elevated Maternal Serum Alpha-Fetoprotein and Normal

Amniotic Fluid Alpha-Fetoprotein

Jaffa, A. (Tel Aviv); Yaron, Y. (Tel Aviv/Detroit, Mich.); Har-Toov, J.; Amster, R; Legum, C;

Lessing, J.B. (Tel Aviv)

89 Erythromycin Treatment for Subclinical

Ureaplasma urealyticum Infection in Preterm Labor

Antsaklis, A.; Daskalakis, G.; Michalas, S.; Aravantinos, D. (Athens)

93 Results and Views of Women in Population-Wide Pregnancy Screening for Trisom $\gamma 21$ in

East Finland

Heikkilä, A.; Ryynänen, M.; Kirkinen, P.; Saarikoski, S. (Kuopio)

97 The Early Amniocentesis Study: A Randomized Clinical Trial of Early Amniocentesis and

Midtrimester Amniocentesis.

II. Evaluation of Procedure Details and Neonatal Congenital

Anomalies

Wilson, R.D. (Vancouver); Johnson, J.; Windrim, R. (Toronto); Dansereau, J.;

Singer, J. (Vancouver); Winsor, E.J.T. (Toronto); Kalousek, D. (Vancouver)

102 Effect of Hispanic Ethnicity on Interpretation of Maternal Serum Screening

Byrne, J.L.B.; Waller, D.K.; Rose, E.; Elias, S. (Houston, Tex.)

107 Abstracts of the 13th International Congress 'The Fetus as a Patient'

Basel, Switzerland, June 13-15,1997

130 Announcements

No. 3

131 Editorial

Holzgreve, W. (Basel) 
132 Transvaginal Ultrasound Detection of Septated and

Non-Septated Cystic Hygroma in Early Pregnancy

Rosati, P.; Guariglia, L. (Rome)

136 First-Trimester Needle Embryofetoscopy and Prenatal Diagnosis

Reece, E.A.; Homko, C.J.; Koch, S.; Chan, L. (Philadelphia, Pa.)

\section{KARGEK}

Fax+41 613061234 E-Mail karger@,karger.ch www.karger.com

(C)1997S. KargerAG, Basel

The list of contents is available at: www.karger.com/journals/fdt/fdtcont.htm

140 On the Complication Risk of Early Amniocentesis versus Standard Amniocentesis

Eiben, B.; Hammans, W.; Hansen, S.; Trawicki, W.; Osthelder, B.; Stelzer, A.; Jaspers, K.-D.;

Goebel, R. (Oberhausen)

145 Glycine as a Potential Window for Minimal Access Fetal Surgery

Ford, W.D.A.; Cool, J.C.; Byard, R,; Allanson, M. (Adelaide) 149 Effects of intravascular

Transfusion for Red Cell Alloimmunization on Fetal Arterial Blood Pressure

Goodrum. L.A.; Moise, K.J., Jr.; Saade. G.R.; Belfort, M.A.; Ayres, N.A.; Carpenter, R.J., Jr.

153 Prenatal Diagnosis of Trisomy 21 in Monozygotic Twins with Increased Nuchal

Translucency and Abnormal Serum Biochemistry

Verdin, S.M.; Braithwaite, J.M. (London); Spencer, K. (Romford); Economides, D.L. (London) 156 Limited Effectiveness of Femur and Humerus Shortening as Markers of Down Syndrome in Early Midtrimester Fetuses

Borrell, A.; Costa, D.; Ojuel, J.; Martinez, J.M.; Seres, A.; Margarit, E.; Fortuny, A. (Barcelona)

163 Placental Lesions: Is Growth a Predictor of Bad Outcome?

Rodriguez, J.G.; Porter, H.J.; Andrews, H.S.; Soothill. P.W. (Bristol)

167 Fetal Bradycardia following Vibratory Acoustic Stimulation: A Sign of Distress?

Ruach, M.; Ohel, G.; Jacobi, N. (Tiberias/Tel Aviv)

170 Effect of Antenatal Betamethasone and Dexamethasone Administration on Fetal Heart Rate Variability in Growth-Retarded Fetuses

Multon, O.; Senat, M.-V.; Minoui, S,; Hue, M.-V.; Frydman, R.; Ville, Y. (Clamart)

178 Transvaginal Color Doppler Assessment of Fetal Circulation in Normal Early Pregnancy

Alcazar, J.L.; Rovira. J.; Ruiz-Pérez, M.L.; López-García, G. (Pamplona) 185 First-Trimester

Diagnosis of Conjoined Twins

Hubinont, C; Kollmann, P.; Malvaux, V.; Donnez, J.; Bernard, P. (Brussels)

188 Amnioinfusion with Hartmann's Solution: A Safe Distention Medium for Endoscopic Fetal Surgery in the Ovine Model

Evrard, V.A.C.; Verbeke, K.; Peers, K.H.; Luks, F.I.; Lerut, A.E.; Vandenberghe, K.; Deprest, J.A.M. (Leuven)

193 Letter to the Editor Concerning the Article by Sohn C et al,: Laser-Induced Thermotherapy for Severe Twin-Twin Transfusion Syndrome

Deprest, J.; Van Schoubroeck, D.; Vandenberghe, K. (Leuven); Ville, Y.; Gagnon, A. (London); Hecher, K,; Hackeloër, B.J. (Hamburg)

No. 4

195 Editorial

Pringle, K.C. (Wellington)

197 Second-Trimester Diagnosis of Fetal Cataract in a Fetus with Walker-Warburg Syndrome 
Beinder, E.J.; Pfeiffer, R.A.; Bomemann, A.; Wenkel, H. (Erlangen)

200 Antenatal Diagnosis and Treatment of Fetal Hypothyroidism.

A Report of Two Cases Bruner, J.P.; Dellinger, E.H. (Nashville, Tenn.) 205 Fetal Tachycardia:

Intrauterine and Postnatal Course

Naumburg, E.; Riesenfeld, T.; Axelsson. O. (Uppsala)

210 Trisomy 21 Placentas: Histopathological and

Immunohistochemical Findings using Proliferating Cell Nuclear Antigen

Qureshí, F.; Jacques, S.M.; Johnson, M.P.; Hume, R.F., Jr.; Kramer, R.L.; Yaron, Y,; Evans, M.I. (Detroit, Mich.)

216 Management of the Fetus with a Correctable Malformation in Paris Maternity Units:

Evolution 1985-1994

De Vigan, C; Goujard, J.; Vodovar, V.; Uzan, S. (Paris)

221 Aspiration of Giant Hepatic Cyst in the Fetus in utero

Ito, M.; Yoshimura, K.; Toyoda, N.; Tanaka, H. (Mie) 226 Fetal Pulmonary Artery Doppler

Waveform: A Preliminary Report

Cynober, E. (Saint Maurice); Cabrol, D. (Paris); Haddad, B. (Créteil); Gabriel, C. (Suresnes);

Moretti, J.L. (Bobigny); Gamghui. S,; Jeny, R. (Saint Maurice)

232 In utero Partial Liver Resection in the Rabbit Model: A Study on Fetal Tissue Regeneration

Patricolo, M,; Zangari, A. (Rome); Paolocci, N.; Magni, F.; Viola-Magni, M.P. (Perugia);

Hernandez-Mena, L.A.; Capuano, L,; Rivosecchi, M. (Rome)

236 First Trimester Fetal Heart Rate: Response to Chorionic Villus Sampling in the

Chromosomally Normal Fetus

Wilson, R.D.; Gibson, W,; Bebbington, M,; Walker, M.; Shaw, D. (Vancouver, B.C.)

241 Large Placental Chorioangiomas as a Cause of Cardiac Failure in Two Fetuses

Horigome, H.; Hamada, H,; Sohda, S.; Igari, M.; Nagata, M.; Okuno, S.; Wada, A.; Kubo. T.

(Tsukuba)

244 Is Inflammation on Papanicolaou Smear a Risk Factor for Preterm Delivery?

Lanouette, J.M.; Puder, K.S.; Berry, S.M.; Bryant, D.R.; Dombrowski, M.P. (Detroit, Mich.)

248 Meconium Drug Screening of Stillborn Infants: A Feasibility Study

Lauria, M.R.; Qureshi, F.; Jacques, S.M.; Kurtzhals, P.; Ostrea, E.M.; Gonik, B.; Sorokin, Y.

(Detroit, Mich.)

252 Cordocentesis Using the Combined Technique: Needle Guide-Assisted and Free-Hand

Petrikovsky, B,; Schneider, E.P.; Klein, V.R.; Wyse, L.J. (Manhasset, NY.)

No. 5

255 Isolated Fetal Choroid Plexus Cysts: Not an Indication for Genetic Diagnosis?

Sohn, C; Gast, A.-S.; Krapfl, E. (Heidelberg)

260 Prenatal Diagnosis of Laryngotracheoesophageal Clefts

Samuel, M,; Burge, D.M.; Griffiths, D.M. (Southampton)

266 Prenatal Diagnosis of Total Anomalous Pulmonary Venous Connection with Asplenia

Yasukochi, S.; Satomi, G,; Iwasaki, Y. (Toyoshina)

270 Cardiac Expression of Sarcoplasmic Reticulum Calcium

ATPase in Fetuses with Trisomy 21 and Trisomy 18 Presenting with Nuchal Translucency

von Kaisenberg, C.S. (Kiel); Huggon, I.; Hyett, J.A.; Farzaneh, F.; Nicolaides, K.H. (London)

274 Emergency Cervical Cerclage after 20 Weeks' Gestation: A Retrospective Study of 6 Years'

Practice in 34 Cases

Benifla, J.L.; Goffinet, F.; Darai, E.; Proust, A.; De Crepy, A.; Madelenat, P. (Paris) 
279 Concordance for Cloacal Dysgenesis

Kramer, R.L.; Johnson, M.P.: Qureshi, F.; Jacques, S.M.; Yaron, Y.; Evans, M.I. (Detroit, Mich.) 283 Mosaic Isochromosome 20q and Normal Outcome: A New Case Ascertained by

Fluorescence in situ Hybridization and a Review of the Literature

Dupont, J.-M.; Le Tessier, D.; Baverel, F.; Rouffet, A.; Rabineau, D. (Paris)

286 Antenatal Diagnosis of Brain Damage in the Survivor after the Second Trimester Death of a Monochorionic Monoamniotic Co-Twin. Case Report and Literature Review Langer, B.;

Boudier, E.; Gasser, B.; Christmann, D.; Messer, J.; Schlaeder, G. (Strasbourg)

292 Vascular Disruption Birth Defects and History of Prenatal Cocaine Exposure: A Case

Control Study

Hume, R.F., Jr.; Martin, L.S.: Bottoms. S.F.; Hassan, S.S.; Banker-Collins. K,; Tomlinson, M.; Johnson, M.P.: Evans, M.I. (Detroit, Mich.)

Contents

Fetal Diagn Ther Vol. 12, 1997 III

296 Intrauterine Cephalocentesis: A Case Report

Bakos, O. (Uppsala)

298 Pitfalls of the 'Double Bubble' Sign: A Case of Congenital Duodenal Duplication

Malone, F.G.; Crombleholme, T.M.; Nores, J.A.; Athanassíou, A.; D’Alton, M.E. (Boston, Mass.)

301 No Effect of Fetal Sex on Amniotic Fluid Alpha-Fetoprotein

Drugan, A. (Haifa/Detroit, Mich.); Yaron, Y.; Murphy, J,; Ebrahim, S.A.D.; Kramer, R.L.; Johnson, M.P.; Evans, M.I. (Detroit, Mich.)

304 Differences in Measurements of the Atria of the Lateral Ventricle: Does Gender Matter? Kramer, R.L.; Yaron, Y.; Johnson, M.P.; Evans, M.I.; Treadwell, M.C.; Wolfe, H.M. (Detroit, Mich.)

306 Is It Possible to Differentiate between Choledochal Cyst and Congenital Biliary Atresia (Type I Cyst) by Antenatal Ultrasonography?

Matsubara, H.; Ohya, N.; Suzuki, Y.; Kajiura, S.; Suzumori, K; Matsuo, Y.; Suzuki, T.;

Hashimoto, T. (Nagoya)

309 Fluorescence in situ Hybridization (FISH) as a Method to Detect Aneuploid Cells

Wei, H.-J.; Su, T.-H.; Chien, C.-L.; Tzeng, C.-R. (Taipei)

314 Cardiovascular Responses of Goat Fetuses to Hypercapnia during Extrauterine Incubation Using Extracorporeal Membrane Oxygenation

Itoh, S.; Yoshida, K; Nakamura, Y.; Mitsuhashi, N.; Kuwabara, Y. (Tokyo)

No. 6

319 Computerised Analysis of Fetal Behaviour

Vindla, S.; Sahota, D.S. (Nottingham); Coppens, M. (Edegem); James, D.K. (Nottingham)

328 Successful Treatment of Supraventricular Tachycardia with Flecainide Acetate: A Case

Report

Amano, K.; Harada, Y.; Shoda, T.; Nishijima, M.; Hiraishi, S. (Kanagawa)

332 Alterations in Ventricular Filling in Small-for-Gestational-Age Fetuses

Miyague, N.I.; Ghidini, A.; Fromberg, R.; Miyague, L.L.T. (Washington, D.C.)

336 Urine B-Core Fragment, a Potential Screening Test for Ectopic Pregnancy and Spontaneous Abortion

Cole, LA.; Isozaki, T.; Jones, E.E. (New Haven, Conn.) 
340 Urinary B-Core Fragment as a Predictor of Abnormal Pregnancy at 4-6 Weeks' Gestation Cardwell, L.; Kowalczyk, C.L.; Rrivchenia, E.L. (Detroit, Mich.); Leon, J. (San Juan Capistrano, Calif.); Evans, M.I. (Detroit, Mich.)

343 Fetal Urine Production Rates following Intrauterine Transfusion

Barrett, J.F.R.; McParland, P.; Macphail, S.; Ryan, G.; Morrow, R. (Toronto)

348 Umbilical Venous Pressure Is Unaltered by Severe, Early-Onset Growth Restriction

Weiner, C.P. (Baltimore, Md.) 353 Doppler Velocimetry of the Umbilical Artery as a Predictor of Outcome in Pregnancies Characterized by Elevated Beta-Subunit Human Chorionic

Gonadotropin

Yaron, Y. (Tel Aviv/Detroit, Mich.); Jaffa, A.J.; Har-Toov, J.; Lavi, H.; Legum, C. (Tel Aviv);

Evans, M.I. (Detroit, Mich.)

356 Evaluation of Early Second Trimester Maternal Serum

Creatine Kinase Isoenzyme BB as a Marker of Poor Pregnancy Outcome

Jenkins, C.B.; Ghidini, A.; Spong, C.Y.; Eglinton, G.S.; Pezzullo, J.C.; Michejda, M.

(Washington, D.C.)

360 Prenatal Diagnosis of Right Lung Agenesis Using Color Doppler and Magnetic Resonance Imaging

Kalache, K.D.; Chaoui, R.; Paris, S.; Bollmann, R. (Berlin)

363 Monochorionic Quadramniotic Quadruplets: Sonographic Workup

Timor-Tritsch, I.E. (New York, N.Y.); Fleischer, A. (New Hyde Park, N.Y.); Monteagudo, A. (New York, N.Y.); Valderrama, E. (New Hyde Park, N.Y.)

368 Author Index Vol. 12,1997 370 Subject Index Vol. 12,1997

\section{KARGEK}

\section{S. Karger}

Medical and Scientific Publishers Basel · Freiburg · Paris · London New York · New Delhi ·

Bangkok Singapore $\cdot$ Tokyo $\cdot$ Sydney

Drug Dosage

The authors and the publisher have exerted every effort to ensure that drug selection and dosage set forth in this text are in accord with current recommendations and practice at the time of publication. However, in view of ongoing research, changes in government regulations, and the constant flow of information relating to drug therapy and drug reactions, the reader is urged to check the package insert for each drug for any change in indications and dosage and for added warnings and precautions. This is particularly important when the recommended agent is a new and/or infrequently employed drug.

All rights reserved.

No part of this publication may be translated into other languages, reproduced or utilized in any form or by any means, electronic or mechanical, including photocopying, recording, microcopying, or by any information storage and retrieval system, without permission in writing from the publisher or, in the case of photocopying, direct payment of a specified fee to the Copyright Clearance Center (see 'General Information').

(C) Copyright 1997 by S. Karger AG, P.O. Box, CH-4009 Basel (Switzerland) Printed in Switzerland on acid-free paper by Reinhardt Druck, Basel

IV

Fetal Diagn Ther Vol. 12, 1997 
Contents 